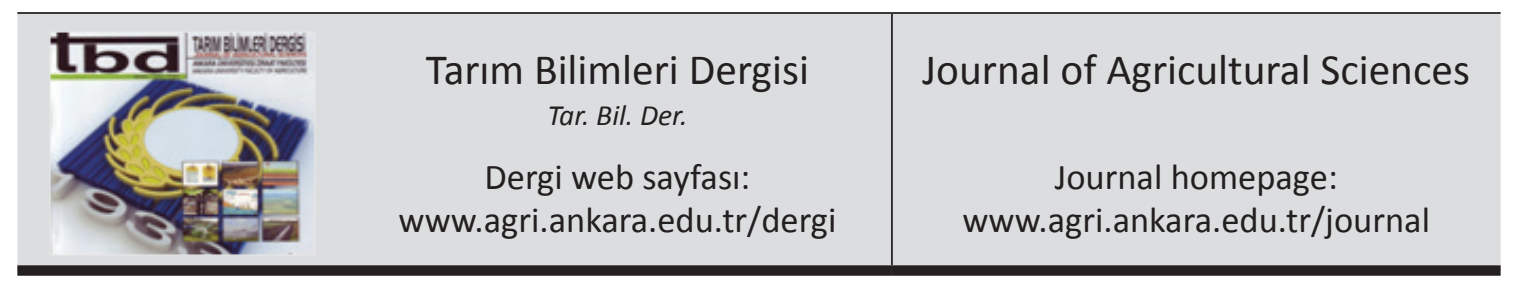

\title{
Effects of Different Sweet Cherry Rootstocks and Drought Stress on Nutrient Concentrations
}

\author{
Zeliha KÜÇÜKYUMUK ${ }^{\mathrm{a}}$, Cenk KÜÇÜKYUMUK ${ }^{\mathrm{b}}$, İbrahim ERDAL ${ }^{\mathrm{a}}$, Figen ERASLAN ${ }^{\mathrm{a}}$ \\ a Suleyman Demirel University, Agricultural Faculty, Department of Soil Science and Plant Nutrition, 32260, Isparta, TURKEY \\ ${ }^{\boldsymbol{b}}$ Fruit Growing Research Station, 32500, Ë̆irdir, Isparta, TURKEY
}

\section{ARTICLE INFO}

Research Article

DOI: 10.1501/Tarimbil 0000001346

Corresponding Author: Zeliha KÜÇÜKYUMUK, E-mail: zelihakucukyumuk@sdu.edu.tr, Tel:+90 (246) 2118642

Received: 20 February 2014, Received in Revised Form: 30 August 2014, Accepted: 17 September 2014

\begin{abstract}
Relation between drought stress, genotypic differences and nutrients are important in plant growth. The aim of the study was to determine the effects of different sweet cherry rootstocks grown in 50-liter pots and drought stress on nutrient $(\mathrm{N}$, $\mathrm{P}, \mathrm{K}, \mathrm{Ca}, \mathrm{Mg}, \mathrm{Zn}, \mathrm{Mn}$, and $\mathrm{Cu}$ ) concentrations of leaves. In this study 0900 Ziraat sweet cherry variety grafted on five different rootstocks (P. mahaleb, Mazzard, Gisela-6, MaxMa 14, CAB 6) were used. Four irrigation treatments (control or $100 \%, 75 \%, 50 \%$, and $25 \%$ and of the field capacity) were used and irrigation intervals were four days in the study. As a result, mineral concentrations of leaves were changed with both rootstocks and drought stress treatments. In general, "Mazzard and Gisela 6" sweet cherry rootstocks had higher nutrient concentrations than "MaxMa 14" under drought stress conditions. The results showed that drought stress reduced the concentration of $\mathrm{N}, \mathrm{P}, \mathrm{K}, \mathrm{Ca}, \mathrm{Mg}, \mathrm{Zn}, \mathrm{Mn}$, and $\mathrm{Cu}$ concentrations. CAB 6 rootstock was not affected by water deficiencies and had higher performance on nutrition than the other rootstocks under drought stress conditions. In conclusion, drought stress and rootstocks have substantial effects on nutrient concentrations of sweet cherry leaves.
\end{abstract}

Keywords: Drought stress; Nutrient concentrations; Sweet cherry rootstocks

\section{Kirazın Mineral Beslenmesi Üzerine Farklı Anaçlar ve Kuraklık Stresinin Etkisi}

ESER BILGISII

Araştırma Makalesi

Sorumlu Yazar: Zeliha KÜÇÜKYUMUK, E-posta: zelihakucukyumuk@sdu.edu.tr, Tel:+90 (246) 2118642

Geliş Tarihi: 20 Şubat 2014, Düzeltmelerin Gelişi: 30 Ağustos 2014, Kabul: 17 Eylül 2014

ÖZET

Bitki yetiştiriciliğinde, kuraklık stresi, genotipik farklılık ve besin elementleri arasındaki ilişkiler önemlidir. Bu çalışmada 50 litrelik saksılarda yetiştirilen kirazın mineral beslenmesi $(\mathrm{N}, \mathrm{P}, \mathrm{K}, \mathrm{Ca}, \mathrm{Mg}, \mathrm{Zn}, \mathrm{Mn}, \mathrm{Cu})$ üzerine farklı anaçlar ve kuraklık stresinin etkilerini belirlemek amaçlanmıştır. Çalışmada, beş farklı (P. mahaleb, Mazzard, Gisela-6, MaxMa 14, CAB 6) anaç üzerine aşılı 0900 Ziraat kiraz çeşidi kullanılmıştır. Denemede kontrol (her sulamada eksik 
nem tarla kapasitesine getirilene kadar sulama) ve 3 farklı su seviyesi (tarla kapasitesinin \% 25, \% 50 ve $\% 75^{\prime}$ i) olmak üzere dört farklı sulama uygulaması yer almıştır. Denemede evapotraspiraasyonla eksilen su dört günde bir tamamlanmıştır. Sonuç olarak, bitkilerin mineral beslenmeleri farklı anaç ve kuraklık stresinden etkilenmiştir. Genellikle kuraklık stresi koşullarında "Mazzard ve Gisela 6" anaçları "MaxMa 14" anacına göre daha fazla besin elementi konsantrasyonuna sahip olmuştur. Sonuçlar, kuraklık stresinin N, P, K, Ca, Mg, Zn, Mn ve Cu konsantrasyonlarını düşürdüğünü göstermiştir. Kuraklık stresinde, CAB 6 anacının beslenme performansına etkisi diğer anaçlara göre daha yüksek bulunmuş ve kısıtlı sulamadan etkilenmemiştir. Sonuç olarak, kuraklık stresi ve farklı anaçların kiraz yaprakları besin elementi konsantrasyonları üzerine etkisi önemli bulunmuştur.

Anahtar Kelimeler: Kuraklık stresi; Besin elementi içeriği; Kiraz anaçları

(C) Ankara Üniversitesi Ziraat Fakültesi

\section{Introduction}

Sweet cherry is an important and common economic fruit tree in the world and in Turkey. Besides having 403.128 tonnes production, Turkey is the leader of the sweet cherry production in the world (FAO 2013). Rootstock-scion relations affect plant growth by influencing the nutritional status and adaptation ability of scion to changing environment. Despite they are grown in the same conditions, mineral concentrations of plants may change (Bergmann 1992; Kacar 1995; Marshner 1995). Studies have shown that rootstocks can affect root and tree growth, yield and quality of sweet cherry fruits (Betran et al 1997; Sitarek et al 1998; Roversi et al 2010; Jimenez et al 2007; Sotirov 2011). Since these differences may change yield and mobility of nutrient concentrations, using different rootstocks should be taken into consideration for obtaining better performance in changing growth environment (Kucukyumuk \& Erdal 2011).

Increasing world population threatens the amount of water used in agriculture in the future (Yurtseven et al 2014). Decrease in water used in agriculture may lead the drought stress in plant production which may cause decrease in photosynthesis and transpiration of mechanisms for the regulation to drought stress depending on plant variety (Mengel \& Kirkby 2001; Sarker et al 2005). Relations among drought stress, nutrients and genotypic variability in nutrient use of sweet cherry rootstocks are important in sweet cherry growth. Since root growth, nutrient transport to rhizophere and solubility of nutrients in soils are inversely related to water deficiency in the soils, nutrient uptake and transport in the plants are negatively affected under water scarcity (Güneş et al 2006).

The use of drought tolerant rootstocks can have positive effects on fruit yield and quality under stress conditions. Rootstocks can show different ability to use available water in the soil profile depending on the root structure and density (Romero et al 2006). However, there are very limited numbers of research dealing with the effect of rootstock-scion relation on nutritional status of sweet cherry under water stress. Güneş et al (2006) reported that drought stress reduced growth of plant and enhanced nutrient uptake in drought resistant rootstocks.

For economically feasible and environmentally friendly fertilization program, using drought resistant rootstocks should be taken as a practical agricultural approach. Therefore, the aim of this study was to test the effects of five commonly used rootstocks-scion relations for nutritional status of scion under drought stress in a greenhouse study.

\section{Material and Methods}

\subsection{Plant material}

In this study 0900 Ziraat sweet cherry variety grafted on five different rootstocks ( $P$. mahaleb, Mazzard, Gisela-6, MaxMa 14, CAB 6) were used. These rootstocks and the variety are commonly used in sweet cherry orchards in either Turkey or in the world. One year old sweet cherries budded on the rootstocks were planted in 50-liter pots containing $40 \mathrm{~kg}$ of soil:peat:farmyard manure:sand 
mixture at the rate of 2:1:0.5:1 (on weight base) on $15^{\text {th }}$ of February. The experiment was conducted in completely randomised design under greenhouse conditions in 2012 vegetation season.

Some characteristics of the experimental growth media were: $\mathrm{pH} 7.4$, organic matter 34.0 $\mathrm{g} \mathrm{kg}^{-1}, \mathrm{CaCO}_{3}$ equivalent $88.0 \mathrm{~g} \mathrm{~kg}^{-1}, \mathrm{NaHCO}_{3}$ extractable $\mathrm{P} 44.1 \mathrm{mg} \mathrm{kg}^{-1}$, molar ammonium acetate exchangeable $\mathrm{K} 401 \mathrm{mg} \mathrm{kg}^{-1}$, Ca $2908 \mathrm{mg} \mathrm{kg}^{-1}$, and $\mathrm{Mg} 239 \mathrm{mg} \mathrm{kg}^{-1}$.

By considering the fertilization requirement of the growth media the following fertilization program were made: $124 \mathrm{mg} \mathrm{kg}^{-1} \mathrm{~N}$ (ammonium nitrate), $23.0 \mathrm{mg} \mathrm{kg}{ }^{-1} \mathrm{~N}, 105 \mathrm{mg} \mathrm{kg}^{-1}$ (mono ammonium phosphate), $163 \mathrm{mg} \mathrm{kg}^{-1} \mathrm{~K}_{2} \mathrm{O}$ (potassium sulphate) and $98.2 \mathrm{mg} \mathrm{kg}^{-1} \mathrm{MgO}$ (magnesium sulphate). After fertilization the growth media was thoroughly mixed to maintain the homogeneity.

\subsection{Irrigation treatments}

Four irrigation schemes were used in order to induce different degrees of drought stress. They are: I) field capacity (T1, control), II) $75 \%$ of field capacity (T2), III) $50 \%$ of field capacity (T3), and IV) $25 \%$ of field capacity (T4). The first irrigation was made in the middle of May and then the evapo-transporated water was added by weighting in four days interval. The irrigation water was supplied from a ground water well by pumping. Some chemical properties of the irrigation water were given in Table 1 .

\subsection{Sampling and plant analysis}

Sweet cherry leaf samples were collected on $15^{\text {th }}$ August. Samples were washed and dried at $65 \pm 5$ ${ }^{\circ} \mathrm{C}$ until a constant weight. Leaf samples were grounded and $0.25 \mathrm{~g}$ of samples was wet-digested with $10 \mathrm{~mL} \mathrm{HNO}_{3}$ at $180{ }^{\circ} \mathrm{C}$ by microwave oven for 15 min. (CEM Mars X-press). Then the digest filled up to $50 \mathrm{ml}$ with de-ionised/distilled water. Phosphorus concentrations were analysed colorimetrically by vanadate-molybdate reagent (Shimadzu UV/VIS 1208); K, Ca, Mg, Zn, Mn and $\mathrm{Cu}$ concentrations were analysed by using atomic absorption spectrophotometer (Varian AAS 240 FS). Total nitrogen was analysed according to Kjeldahl method (Kacar \& İnal 2008).

\subsection{Experiment design and statistical analysis}

The pot experiment was set up in completely randomized design with factorial arrangement in triplicates. Statistical analyses were conducted using analysis of variance (ANOVA) using SAS programme (Statistical Analysis Software). The mean separation between the treatments' averages was made by Duncan's Multiple Range Test ( $\mathrm{P} \leq$ $0.05)$.

\section{Results and Discussion}

Rootstocks and drought stress had significant effects on total $\mathrm{N}$ concentrations of leaves (Table 2). Trees on "Mazzard and Gisela 6" had significantly higher leaf-N concentrations than the other rootstocks. As previously reported, rootstocks influenced the $\mathrm{N}$ nutrition status of sweet cherry trees and the differences among the rootstock-scions were attributed to mineral uptake capacity of rootstocks due to their changing root structure (Abrisqueta et al 2011). The main effects of irrigation treatments on leaf-N concentrations were significant and $\mathrm{N}$ concentration decreased with increasing water stress. The highest $\mathrm{N}$ concentration was obtained for the control treatment $\left(33 \mathrm{~g} \mathrm{~kg}^{-1}\right)$ and it decreased down to $27 \mathrm{~g} \mathrm{~kg}^{-1}$ for $25 \%$ irrigation of field capacity (T4). Similar effects of water scarcity or drought

Table 1- Some chemical properties of irrigation water

Çizelge 1-Sulama suyunun bazı kimyasal özellikleri

\begin{tabular}{|c|c|c|c|c|c|c|c|c|c|c|c|c|}
\hline \multirow{2}{*}{$\begin{array}{c}\text { Class of irrigation } \\
\text { water }\end{array}$} & \multirow{2}{*}{$\begin{array}{c}\text { umhos } \\
\mathrm{cm}^{-1}\end{array}$} & \multirow{2}{*}{$p H$} & \multicolumn{4}{|c|}{ Cations ( $\left.m g L^{-1}\right)$} & \multicolumn{4}{|c|}{ Anions ( $m g L^{-1}$ ) } & \multirow{2}{*}{$\mathrm{Na}(\%)$} & \multirow{2}{*}{$S A R$} \\
\hline & & & $\mathrm{Na}^{+}$ & $K^{+}$ & $\mathrm{Ca}^{2+}$ & $\mathrm{Mg}^{2+}$ & $\mathrm{CO}_{3}^{-}$ & $\mathrm{HCO}_{3}^{-}$ & $\mathrm{Cl}^{-}$ & $\mathrm{SO}_{4}^{2-}$ & & \\
\hline $\mathrm{C}_{2} \mathrm{~S}_{1}$ & 310 & 7.8 & 7 & 4 & 44.1 & 46.2 & - & 20.2 & 48.6 & 32.5 & 6.9 & 1.04 \\
\hline
\end{tabular}

Tarım Bilimleri Dergisi - Journal of Agricultural Sciences 21 (2015) 431-438 
Table 2- Effect of different rootstocks and drought stress on $\mathbf{N}$ and $\mathbf{P}$ concentrations of leaves $\left(\mathrm{g} \mathrm{kg}^{-1}\right)$ Çizelge 2- Farklı anaç ve kuraklı stresinin yaprağın $N$ ve P içeriklerine etkisi $\left(\mathrm{g} \mathrm{kg}^{-1}\right)$

Irrigation treatments

Rootstocks

\begin{tabular}{|c|c|c|c|c|c|c|c|c|c|c|}
\hline & \multicolumn{2}{|c|}{$T 1$} & \multicolumn{2}{|c|}{$T 2$} & \multicolumn{2}{|c|}{$T 3$} & \multicolumn{2}{|c|}{$T 4$} & \multicolumn{2}{|c|}{ Mean } \\
\hline & $N$ & $P$ & $N$ & $\boldsymbol{P}$ & $N$ & $\boldsymbol{P}$ & $N$ & $\boldsymbol{P}$ & $N$ & $\boldsymbol{P}$ \\
\hline P.Mahaleb & 30 & 2.9 & 30 & 2.9 & 26 & 2.8 & 26 & 2.9 & $28 C^{*}$ & 2.9 \\
\hline Mazzard & 38 & 3.0 & 34 & 2.8 & 32 & 2.9 & 28 & 2.8 & $33 \mathrm{~B}$ & 2.9 \\
\hline Gisela 6 & 45 & 2.7 & 36 & 2.8 & 36 & 2.9 & 34 & 3.0 & $38 \mathrm{~A}$ & 2.9 \\
\hline MaxMa 14 & 28 & 3.1 & 28 & 2.9 & 24 & 2.8 & 20 & 2.6 & $25 \mathrm{C}$ & 2.9 \\
\hline CAB 6 & 26 & 2.6 & 26 & 2.9 & 24 & 3.0 & 26 & 2.9 & $26 \mathrm{C}$ & 2.9 \\
\hline Mean & $33 a^{* *}$ & $2.9 \mathrm{a}^{* *}$ & $31 \mathrm{ab}$ & $2.9 \mathrm{~b}$ & $28 b c$ & $2.9 \mathrm{~b}$ & $27 \mathrm{c}$ & $2.8 \mathrm{~b}$ & & \\
\hline
\end{tabular}

Table 3- Effect of different rootstocks and drought stress on $\mathrm{K}$ and $\mathrm{Ca}$ concentrations of leaves ( $\left.\mathrm{g} \mathrm{kg}^{-1}\right)$

Çizelge 3- Farklı anaç ve kuraklık stresinin yaprağın K ve Ca içeriklerine etkisi $\left(\mathrm{g} \mathrm{kg}^{-1}\right)$

Irrigation treatments

Rootstocks

\begin{tabular}{lcccccccccc}
\hline & \multicolumn{2}{c}{$T 1$} & \multicolumn{2}{c}{$T 2$} & \multicolumn{2}{c}{$T 3$} & \multicolumn{2}{c}{ Mean } \\
& $K$ & $C a$ & $K$ & $C a$ & $K$ & $C a$ & $K$ & $C a$ & $K$ & $C a$ \\
\hline P.Mahaleb & $35 \mathrm{Aa}^{*}$ & $19 \mathrm{Ad}^{* *}$ & $33 \mathrm{Bab}$ & $18 \mathrm{ABc}$ & $31 \mathrm{Ca}$ & $17 \mathrm{Bcd}$ & $31 \mathrm{Ca}$ & $15 \mathrm{Cd}$ & 33 & 17 \\
Mazzard & $36 \mathrm{Aa}$ & $17 \mathrm{Ae}$ & $34 \mathrm{Ba}$ & $16 \mathrm{ABd}$ & $32 \mathrm{Ca}$ & $16 \mathrm{ABd}$ & $32 \mathrm{Ca}$ & $15 \mathrm{Bd}$ & 33 & 16 \\
Gisela 6 & $33 \mathrm{Ab}$ & $32 \mathrm{Aa}$ & $32 \mathrm{Ab}$ & $31 \mathrm{Aa}$ & $32 \mathrm{Aa}$ & $25 \mathrm{Ba}$ & $32 \mathrm{Aa}$ & $25 \mathrm{Ba}$ & 32 & 28 \\
MaxMa 14 & $28 \mathrm{Ac}$ & $27 \mathrm{Ab}$ & $25 \mathrm{Bc}$ & $19 \mathrm{Bc}$ & $25 \mathrm{Bb}$ & $18 \mathrm{BCc}$ & $25 \mathrm{Bc}$ & $17 \mathrm{Cc}$ & 26 & 20 \\
CAB 6 & $35 \mathrm{Aa}$ & $23 \mathrm{Ac}$ & $32 \mathrm{Bb}$ & $22 \mathrm{Ab}$ & $31 \mathrm{Ba}$ & $22 \mathrm{Ab}$ & $28 \mathrm{Cb}$ & $22 \mathrm{Ab}$ & 31 & 22 \\
\hline Mean & 33 & 24 & 31 & 21 & 30 & 20 & 30 & 19 & & \\
\hline
\end{tabular}

Capital letters indicates drought stress and small letters indicates rootstocks differences; *, $\mathrm{K}(\mathrm{P}<0.05)$; **, $\mathrm{Ca}(\mathrm{P}<0.01)$

stress were also reported in the previous studies (Y1 et al 2009; Abrisqueta et al 2011).

The main effect of irrigation treatments on $\mathrm{P}$ concentration of leaves was significant whereas the main effects of rootstocks were non-significant (Table 2). Duncan's multiple range test revealed two homogenous groups. The highest $\mathrm{P}$ concentrations were determined at the control treatment (3.0 $\mathrm{g} \mathrm{kg}^{-1}$ ) and drought stress induced decreases in $\mathrm{P}$ concentrations were observed in this study. Results are also in agreement with those reported by Getachew (2014). In the study, P concentrations decreased with increase in water deficit level. The highest $\mathrm{P}$ concentration was obtained from control conditions $(0 \%)$ and $25 \%$ deficit levels while the lowest was recorded from the highest (75\%) water deficit level.

Table 3 shows the effects of different rootstocks and drought stress on $\mathrm{K}$ concentrations. Interaction of drought stress and rootstocks were found significant. Under control conditions Mazzard (36 $\left.\mathrm{g} \mathrm{kg}^{-1}\right)$, Mahaleb $\left(35 \mathrm{~g} \mathrm{~kg}^{-1}\right)$ and CAB $6\left(35 \mathrm{~g} \mathrm{~kg}^{-1}\right)$ rootstocks had the highest $\mathrm{K}$ concentrations, the lowest $\mathrm{K}$ concentrations determined with MaxMa rootstock $\left(28 \mathrm{~g} \mathrm{~kg}^{-1}\right)$. Except Gisela 6 rootstock, with decreasing amount of water all rootstocks concentrations decreased. Higher K concentrations were found in Mahaleb and Mazzard rootstocks (33.0 $\mathrm{g} \mathrm{kg}^{-1}$ ). In a similar manner, Roversi et al (2010) reported a genotype dependency in leaf K 
concentration and $\mathrm{K}$ nutritional status for sweet cherry. As the main effect of irrigation treatments regarded, maximum $\mathrm{K}$ concentration $\left(33.0 \mathrm{~g} \mathrm{~kg}^{-1}\right)$ was found at control treatment and the minimum was found at T3 and T4 treatments $\left(30.0 \mathrm{~g} \mathrm{~kg}^{-1}\right)$. Other researchers found drought stress influence $\mathrm{K}$ concentrations and $\mathrm{K}$ nutritional status of plants (Sanchez-Rodriguez et al 2012; Nakojima et al 2004). The decrease of $K$ concentrations can be related to reduction of in-flow water in plant. Potassium had important roles on osmoregulation, enzyme activation, neutralization, transport process (Reddy et al 2004). Sufficient K concentrations increase the control over osmotic adjustment which keeps turgor pressure under osmotic stress conditions (Wang et al 2013). Therefore, increased $\mathrm{K}$ concentration in leaves could be an indication of drought stress resistance for any rootstock-scion pair.

As seen in Table 3, Ca concentrations of sweet cherry were influenced by drought stress $x$ rootstock interaction. The highest $\mathrm{Ca}$ concentration (32.0 $\mathrm{g} \mathrm{kg}^{-1}$ ) was found from T1 x Gisela 6 interactions while the lowest $\left(15.0 \mathrm{~g} \mathrm{~kg}^{-1}\right)$ was obtained from T4 x P. Mahaleb. The rootstocks of Mahaleb and Mazzard had the lowest (17.0 and $\left.16.0 \mathrm{~g} \mathrm{~kg}^{-1}\right) \mathrm{Ca}$ concentrations compared to the other rootstocks. While the highest $\mathrm{Ca}$ concentration was determined at $\mathrm{T} 1$, leaf $\mathrm{Ca}$ levels decreased with increasing water deficit. Also limited movement of $\mathrm{Ca}$ through the roots due to deficit mass flow may result $\mathrm{Ca}$ deficiency under water deficit conditions (Kacar \& Katkat 1998). Mean values of Ca concentrations decreased with irrigation treatments and varied with different rootstocks. While Gisela 6 had the highest (28.0 $\left.\mathrm{g} \mathrm{kg}^{-1}\right) \mathrm{Ca}$ concentrations Mazzard had the lowest $\left(16 \mathrm{~g} \mathrm{~kg}^{-1}\right) \mathrm{Ca}$ concentrations.

The lesser amount of irrigation water resulted in the lower $\mathrm{Mg}$ concentration in leaves. The concentrations of $\mathrm{Mg}$ in descending order were 5.2, 4.8, 4.7, and $4.5 \mathrm{~g} \mathrm{~kg}^{-1}$ for $\mathrm{T} 1>\mathrm{T} 2>\mathrm{T} 3>$ T4 treatments, respectively. Romero et al (2006) reported that $\mathrm{Mg}$ concentrations decreased with increasing water deficiency. While Gisela 6 rootstock had the highest $\mathrm{Mg}$ concentrations (6.0 $\left.\mathrm{g} \mathrm{kg}^{-1}\right)$, Mahaleb and Mazzard rootstocks had the lowest (3.9 and $3.8 \mathrm{~g} \mathrm{~kg}^{-1}$ ).

Different rootstocks-scion combinations resulted in significant variation in leaf- $\mathrm{Cu}$ concentrations, whereas there were no significant effects of irrigation treatments (Table 4). Mazzard rootstock had the highest $\left(12 \mathrm{mg} \mathrm{kg}^{-1}\right) \mathrm{Cu}$ concentrations and followed by CAB 6 and Mahalep. Rootstock x drought stress interaction significantly influenced $\mathrm{Zn}$ concentrations (Table 5). Drought stress decreased $\mathrm{Zn}$ concentrations of plants. The highest $\mathrm{Zn}$ concentration was obtained for the control treatment $\left(14 \mathrm{mg} \mathrm{kg}^{-1}\right)$ and increasing water scarcity steadily decreased $\mathrm{Zn}$ levels as 13,12 and $11 \mathrm{mg}$ $\mathrm{kg}^{-1}$ for T2, T3, and T4 treatments, respectively.

Drought stress and rootstocks-scion interaction affected Mn concentrations (Table 5). Differing drought stress resulted in a Mn concentration range of 42 to $50 \mathrm{mg} \mathrm{kg}^{-1}$. Besides CAB 6 rootstock, Mn concentrations of all rootstock-scion combinations used in this study were inversely affected by increasing drought stress. Although Mazzard and Gisela 6 rootstocks-scion combinations better performed in uptake of Mn with $53 \mathrm{mg} \mathrm{kg}^{-1}$ and 51 $\mathrm{mg} \mathrm{kg}^{-1} \mathrm{Mn}$ concentrations whereas Mahaleb and Max Ma 14 rootstocks showed poor performance (40 $\mathrm{mg} \mathrm{kg}^{-1}$ ).

Mineral concentration of leaves was varied by both rootstocks and drought stress treatments. Rootstock-scion combinations were differently influenced from the degrres of drought stress. Such differences can be attributed to variation in nutrient uptake abilities of rootstocks (Marschner et al 1986a, b; Kayan 2008). Result revealed that in general, "Mazzard and Gisela 6" rootstocks-scion combinations have higher nutrient uptake ability than "MaxMa 14".

Results showed that drought stress reduced the concentration of $\mathrm{N}, \mathrm{P}, \mathrm{K}, \mathrm{Ca}, \mathrm{Mg}, \mathrm{Mn}, \mathrm{Zn}$, and $\mathrm{Cu}$ concentrations. Similar results were reported for concentrations of $\mathrm{N}, \mathrm{K}, \mathrm{Ca}$ and $\mathrm{Mg}$ upon increasing drought stress (Nahar \& Gretzmacher 2002). Sivritepe et al (2008) found that K, Ca and Mn concentrations of Gisela 5 rootstock shows 
Table 4- Effect of different rootstocks and drought stress on $\mathrm{Mg}\left(\mathrm{g} \mathrm{kg}^{-1}\right)$ and $\mathrm{Cu}\left(\mathrm{mg} \mathrm{kg}^{-1}\right)$ concentrations of leaves

Çizelge 4- Farklı anaç ve kuraklık stresinin yaprağın $\mathrm{Mg}\left(\mathrm{g} \mathrm{kg}^{-1}\right)$ ve Cu $\left(\mathrm{mg} \mathrm{kg}^{-1}\right)$ içeriklerine etkisi

Irrigation treatments

Rootstocks

\begin{tabular}{|c|c|c|c|c|c|c|c|c|c|c|}
\hline & \multicolumn{2}{|c|}{$T 1$} & \multicolumn{2}{|c|}{$T 2$} & \multicolumn{2}{|c|}{$T 3$} & \multicolumn{2}{|c|}{$T 4$} & \multicolumn{2}{|c|}{ Mean } \\
\hline & $M g$ & $\mathrm{Cu}$ & $M g$ & $\mathrm{Cu}$ & $M g$ & $\mathrm{Cu}$ & $M g$ & $\mathrm{Cu}$ & $M g$ & $\mathrm{Cu}$ \\
\hline P.Mahaleb & 4.3 & 11 & 4.0 & 12 & 4.0 & 10 & 3.3 & 13 & $3.9 C^{*}$ & $11 \mathrm{~B}^{*}$ \\
\hline Mazzard & 4.0 & 13 & 4.0 & 12 & 3.7 & 12 & 3.5 & 16 & $3.8 \mathrm{C}$ & $12 \mathrm{~A}$ \\
\hline Gisela 6 & 6.9 & 10 & 5.7 & 10 & 5.7 & 10 & 5.6 & 9 & $6.0 \mathrm{~A}$ & $10 \mathrm{BC}$ \\
\hline MaxMa 14 & 5.2 & 10 & 5.1 & 10 & 5.1 & 9 & 4.9 & 8 & $5.1 \mathrm{~B}$ & $9 \mathrm{C}$ \\
\hline CAB 6 & 5.7 & 11 & 5.2 & 11 & 5.2 & 11 & 5.2 & 13 & $5.3 \mathrm{~B}$ & $11 \mathrm{~B}$ \\
\hline Mean & $5.2 \mathrm{a}^{* *}$ & 11 & $4.8 \mathrm{~b}$ & 11 & $4.7 \mathrm{~b}$ & 10 & $4.5 \mathrm{c}$ & 10 & & \\
\hline
\end{tabular}

Table 5- Effect of different rootstocks and drought stress on $\mathrm{Zn}$ and $\mathrm{Mn}$ concentrations of leaves (mg kg-1)

Çizelge 5- Farklı anaç ve kuraklık stresinin yaprağın Zn ve Mn içeriklerine etkisi $\left(\mathrm{mg} \mathrm{kg}^{-1}\right)$

Irrigation treatments

Rootstocks

\begin{tabular}{lcccccccccc}
\hline & \multicolumn{2}{c}{$T 1$} & \multicolumn{2}{c}{$T 2$} & \multicolumn{2}{c}{$T 3$} & \multicolumn{2}{c}{ Mean } \\
& $Z n$ & $M n$ & $Z n$ & $M n$ & $Z n$ & $M n$ & $Z n$ & $M n$ & $Z n$ & $M n$ \\
\hline P.Mahaleb & $16 \mathrm{Aa}^{*}$ & $42 \mathrm{Ad}^{* *}$ & $15 \mathrm{Aa}$ & $41 \mathrm{Ab}$ & $11 \mathrm{Bb}$ & $41 \mathrm{Ab}$ & $11 \mathrm{Bb}$ & $36 \mathrm{Bc}$ & 13 & 40 \\
Mazzard & $17 \mathrm{Aa}$ & $56 \mathrm{Aa}$ & $17 \mathrm{Aa}$ & $53 \mathrm{ABa}$ & $16 \mathrm{Aa}$ & $52 \mathrm{ABa}$ & $16 \mathrm{Aa}$ & $50 \mathrm{Ba}$ & 17 & 53 \\
Gisela 6 & $12 \mathrm{Ab}$ & $54 \mathrm{Aab}$ & $10 \mathrm{ABb}$ & $52 \mathrm{Aa}$ & $8 \mathrm{Bc}$ & $52 \mathrm{Aa}$ & $8 \mathrm{Bc}$ & $45 \mathrm{Bb}$ & 10 & 51 \\
MaxMa 14 & $10 \mathrm{Ab}$ & $49 \mathrm{Ac}$ & $9 \mathrm{Ab}$ & $41 \mathrm{Bb}$ & $8 \mathrm{Ac}$ & $41 \mathrm{Bb}$ & $8 \mathrm{Ac}$ & $31 \mathrm{Cd}$ & 9 & 40 \\
CAB 6 & $10 \mathrm{Cb}$ & $50 \mathrm{Abc}$ & $17 \mathrm{Aa}$ & $50 \mathrm{Aa}$ & $17 \mathrm{Aa}$ & $51 \mathrm{Aa}$ & $13 \mathrm{Bb}$ & $50 \mathrm{Aa}$ & 14 & 50 \\
\hline Mean & 14 & 50 & 13 & 47 & 12 & 47 & 11 & 42 & & \\
\hline
\end{tabular}

Capital letters indicates drought stress and small letters indicates rootstocks differences; *, Zn ( $\mathrm{P}<0.01)$; **, Mn $(\mathrm{P}<0.05)$

significant decreases under drought stress. The findings of Brito et al (2003) and Molassiotis et al (2006) showed a decrease in leaf- $\mathrm{K}$ and Mn concentrations of sweet cherry under deficit irrigation.

Nutrient concentrations obtained for different rootstock-scion combinations showed a decreasing tendency to increasing water deficiency, but $\mathrm{N}, \mathrm{P}$, $\mathrm{Ca}, \mathrm{Mn}, \mathrm{Zn}$ and $\mathrm{Cu}$ concentrations of sweet cherry budded on $\mathrm{CAB} 6$ rootstock were not affected from the irrigation treatments. By considering mineral composition of leaves, it can be said that $\mathrm{CAB} 6$ rootstock had higher performance on drought stress than the other rootstocks.
MaxMa 14, Gisela 6, and CAB 6 are the most preferred rootstocks by sweet cherry producers in newly established orchards in the last decade. The reasons of the preference of the rootstocks are earlier yield, higher tree density per ha, ease of cultivation practices such as pruning, harvesting, etc.

\section{Conclusions}

Nutrient concentrations of leaves were affected by rootstocks and drought stress. Result pointed out that in general, "Mazzard and Gisela 6" rootstocksscion combinations had higher nutrient uptake ability than "MaxMa 14". On the other side, drought stress reduced $\mathrm{N}, \mathrm{P}, \mathrm{K}, \mathrm{Ca}, \mathrm{Mg}, \mathrm{Mn}, \mathrm{Zn}$, 
and $\mathrm{Cu}$ concentrations. Results revealed that the lowest nutrient concentration changes of leaves was determined from $\mathrm{CAB} 6$ rootstock. Furthermore, it can be said that $\mathrm{CAB} 6$ rootstock had higher performance on drought stress than the other rootstocks.

Due to increasing global desertification or warming and water scarcity in the last decades, deficit irrigation practice along with drought resistant rootstock-scion combination with minimum yield and quality lost could be considered as economically feasible and environmentally friendly agricultural practice. Therefore, this study supports this idea and results can be used practically by producers. This study has significant attributes for selecting the most tolerant rootstock for water deficit conditions to minimize nutritional disorders of sweet cherry orchards.

\section{References}

Abrisqueta I, Quezada-Martin R, Munguia-Lopez J, Ruiz-Sanchez M C, Abrisqueta J M \& Vera J (2011). Nutrient concentrations of peach-tree leaves under deficit irrigation. Journal of Plant Nutrition and Soil Science 174: 81-87

Bergmann W (1992). Colour Atlas. Nutritional Disorders of Plants. Gustav Fischer Verlag Jena

Betran J A, Val J, Milla'n L M, Monge E, Montañe's L \& Moreno M A (1997). Influence of rootstock on the mineral concentrations of flowers and leaves from sweet cherry. Acta Horticulturae 448: 163-167

Brito G, Costa A, Fonseca H M \& Santos C V (2003). Response of Olea europaea ssp. maderensis in vitro shoots exposed to osmotic stress. Scientia Horticulturae 97: 411-417

Dodd I (2009). Rhizosphere manipulation to maximize 'crop perdrop' during deficit irrigation. Journal of Experimental Botany 60: 2454-2459

FAO (2013). FAO. Erişim Tarihi. 15.05.2013. http:// faostat3.fao.org/home/ index.html\# Download

Getachew M (2014). Influence of Soil Water Deficit and Phosphorus Application on Phosphorus Uptake and Yield of Soybean (Glycine max L.) at Dejen, NorthWest Ethiopia. American Journal of Plant Sciences 5: 1889-1906
Güneş A, Çiçek N, İnal A, Alpaslan M, Eraslan F, Güneri E \& Güzelordu T (2006). Genotypic response of chickpea (Cicer arietinum L.) cultivars to drought stress implemented at pre-and-post anthesis stages and its relations with nutrient uptake and efficiency. Plant and Soil Environment 52: 368-376

Jimenez S, Pinochet Y, Gogorcena J A, Betra'n J A \& Moreno M A (2007). Influence of different vigour cherry rootstocks on leaves and shoots mineral composition. Scientia Horticulturae 112: 73-79

Kacar B (1995). Soil Analysis. Ankara University, Faculty of Agriculture. Ankara, Turkey

Kacar B \& Katkat V (1998). Plant Nutrition. Nobel, Ankara

Kacar B \& İnal A (2008). Plant Analysis, Nobel, Ankara

Kayan N (2008). Variation for yield components in two winter sown lentil cultivars (Lens culinaris Medic.). Bulgarian Journal of Agricultural Science 14: 460465

Küçükyumuk Z \& Erdal İ (2011). Rootstock and cultivar effect in mineral nutrition, seasonal nutrient variation. Bulgarian Journal of Agricultural Science 17(5): 633641

Marschner H, Romheld V \& Kissel M (1986a). Different strategies in higher plants in mobilization and uptake of iron. Journal of Plant Nutrition 9: 695-713

Marschner H, Romheld V, Horst W J \& Martin P (1986b). Root-induced changes in rhizosphere: Importance for the mineral nutrition of plants. Zeitschrift für Pflanzenernährung Bodenkunde 149: 441-456

Molassiotis A N, Sotiropoulos T, Tanou G, Kofidis G, Diamantidis G \& Therios, I (2006). Antioxidant and anatomical responses in shoot culture of the apple rootstock MM 106 treated with $\mathrm{NaCl}, \mathrm{KCl}$, mannitol or sorbitol. Journal of Crustacean Biology 29(3): 293-301

Nahar K \& Gretzmacher R (2002). Effect of water stress on nutrient uptake, yield and quality of tomato (Lycopersicon esculentum Mill.) under subtropical conditions. Die Bodenkultur 53(1): 45-51

Nakajima H, Behboudian M H, Greven M \& ZegbeDomínguez J A (2004). Mineral content of grape, olive, apple and tomato under reduced irrigation. Journal of Plant Nutrition and Soil Science 167: 91-92

Reddy A R, Chaitanya K V \& Vivekanandan M (2004). Drought-induced responses of photosynthesis and 
antioxidant metabolism in higher plants. Journal of Plant Physiology 161: 1189-1202

Romero P, Navarro J M, Pérez-Pérez J, García-Sánchez F., Gómez-Gómez A, Porras I, Martinez V \& Botía P (2006). Deficit irrigation and rootstock: their effects on water relations, vegetative development, yield, fruit quality and mineral nutrition of Clemenules mandarin. Tree Physiology 26(12): 1537-1548

Roversi A, Malvicini G L, Porro D \& Plessi C (2010). Sweet cherry leaf composition as influenced by genotype, rootstock and orchard management. Acta Horticulturae 868: 243-246

Sanchez-Rodriguez E, Leyva R, Consta'n-Aguilar C, Romero L \& Ruiz JM (2012). Grafting under water stress in tomato cherry: improving the fruit yield and quality. Annals of Applied Biology 161: 302-312

Sarker B C, Hara M \& Uemura M (2005). Prolinesynthesis, physiological responses and biomass, yield of eggplants during and after repetitive soil moisture stress. Scientia Horticulturae 103: 387-402

Sitarek M, Grzyb Z S \& Olszewski T (1998). The mineral elements concentration in leaves of two sweet cherry cultivars grafted on different rootstocks. Acta Horticulturae 468: 373-376

Sivritepe N, Ertürk U, Yerlikaya C, Türkan I, Bor M \& Özdemir F (2008). Response of the cherry rootstock to water stress induced in vitro. Biologia Plantarum 52(3): 573-576

Sotirov D (2011). Macro-elements content of the leaves of Van sweet cherry cultivar on different rootstocks. Rastenievudni Nauki 48(1): 43-46

Yl Q, Zhang F C \& Li K F (2009). Effects of water deficit and nitrogen fertilization on winter wheat growth and nitrogen uptake. National Center for Biotechnology Information 20(10): 2399-2405

Yurtseven E, Öztürk H S \& Avc1 S (2014). Mass balance criteria in soil salinity management: Different irrigation water qualities and leaching ratio. Tarm Bilimleri Dergisi - Journal of Agricultural Sciences 20: 103-111

Wang M, Zheng Q, Sheng Q \& Guo S (2013). The critical role of potassium in plant stress response. International Journal of Molecular Sciences 14(4): 7370-7390 